\title{
GUILT AND ITS PURIFICATION
}

The Church and Sexual Abuse

\section{Katharina von Kellenbach}

midst the horror of ongoing revelations about the Roman Catholic Church's complicity in sexual predation, a theological reflection on Christian teachings about guilt and reconciliation is enlightening. Flawed notions of Christian forgiveness have brought us to this point where priests are absolved of crimes by their colleagues and reassigned to different posts in blind faith in their resolve to begin anew. The mystery of redemption is at the heart of the Christian message, which makes this systemic failure sadly predictable and particularly painful. What is wrong with the Christian theory and practice of sin and forgiveness that it fails to resist devastating complicity? Shifting focus from redemption to guilt invites reflection on the problematic metaphors that facilitate quick release and premature closure. The language of guilt invokes the imagery of stains and impurities that must be purified (by the sacrificial blood of Christ) or of burdens and weights that can be lifted and carried away (by a substitutionary scapegoat). In either case, guilt disappears as if by magic. This essay questions this imagery and draws on ecologically informed, sustainable practices of purification in order to propose a sequence of ritual steps to transform personal and collective guilt in the wake of the sexual abuse crisis.

We rarely stop to define guilt, because it is immediately linked to forgiveness. Guilt and forgiveness, sin and redemption are paired concepts that are mentioned in the same breath. But what is guilt? Is it an individual feeling or an objective condition? The term is often used interchangeably, although the emotion and the state of being guilty are, 
unfortunately, very different experiences. In fact, it is one of the cruel ironies that victims feel guilty, while perpetrators remain indifferent to and oblivious about the harm they caused. It is the victims who are wracked by guilt feelings, sometimes severely so. Depression, anxiety, trouble sleeping, and nightmares are common experiences among survivors. The symptom of survivor guilt would eventually be incorporated into the emerging concept of "trauma" and its official clinical diagnosis as PTSD, post-traumatic stress syndrome. ${ }^{1}$ Among its four symptoms, listed by National Institute of Health, are "distorted feelings like guilt or blame" and "negative thoughts about oneself or the world." ${ }^{2}$ Much of the psychoanalytic discourse on guilt is victim-centered since research is driven by patients who consult psychoanalysts and psychotherapists. ${ }^{3}$ And it is the victims of traumatic violence who are plagued by intense emotions of guilt, rage, shame, and powerlessness. Perpetrators rarely consult therapists, counselors, or confessors. As long as perpetrators do not present with symptoms or are required by law to sign up for therapy [as pedophiles and sex offenders must do according to German law], ${ }^{4}$ there are few empirical studies on the symptomology of a "perpetrator syndrome." The diagnosis of "post-traumatic stress syndrome" describes the experience of victims rather than perpetrators.

Martin Buber insisted on the difference between "real" or "ontic" guilt and guilt feelings in a lecture at a Conference on Medical Psychotherapy in 1948, which was subsequently published as "Guilt and Guilt Feelings." A therapist, Buber warned, should not ignore the "external life of his patient and especially the actions and attitudes therein, and again especially the patient's active share in the manifold relation between him and the human world." ${ }^{6}$ There is a difference, Buber argued, between the emotional (neurotic) response and the actual violation of the order of being (Seinsordnung). Guilt and guilt feelings are inversely related: Perpetrators lack feelings of guilt, while victims are wracked by self-blame, shame, and guilt feelings.

The symptoms of guilt manifest as lack of empathy, an absence of sensitivity, an obstruction of moral response to the suffering of others. ${ }^{7}$ To harm another requires a barrier that shields against responsiveness to suffering. Every act of violence involves a hardening of the heart, to use the Biblical concept, on the part of the perpetrator. We will leave aside the theological question of ultimate responsibility and whether it is "The 
LORD [who] hardened Pharaoh's heart” (Ex 10:20; 10:27, 11:10; 14:8; Jos 11:20). Psychologically, denial is cause and effect of harming another being. It is intrinsic to the infliction of harm. "He has blinded their eyes, and hardened their heart, so that they might not look with their eyes and understand with their heart" (John 12:40). Perpetrators avert their eyes and block their ears to avoid seeing, feeling, and hearing the pain inflicted on victims. This is true for all acts of violence, but especially so for agents who act within structures of authority that use legitimate force to maintain order. Hierarchical systems give some people power over others who are deemed essentially different and in need of control because of some perceived lack of rationality, authority, or agency. Ideologies of gender, sexuality, age, ability, race, and class justify why certain people deserve less protection of their integrity and autonomy and somehow feel less pain and suffering. As long as such ideological force fields remain operative, there is no consciousness of culpable wrongdoing. Atrocities, which on Claudia Card's definition include sexual and domestic violence against women and children, suck entire communities into moral indifference, complicity, and denial. ${ }^{8}$

If the dis-ease consists in the absence of cognitive and emotional guilt awareness, then the cure cannot rightly promise release from its burden or purification of its remainders. But this is exactly what the liturgical and sacramental language of reconciliation promises. Built on biblical models of sacrificial atonement, Christ's death saves because his blood washes away sin and because he bears the weight of iniquity. Such metaphors are invoked to explain his death for the "forgiveness of our trespasses" (Eph 2:13), "that he might redeem us from all iniquity and purify for himself a people of his own who are zealous for good deeds" (Titus $2: 14)$. In the sacraments of baptism, "you were washed, you were sanctified, you were justified" (1 Cor 6:11) and of the eucharist, where the "blood of Jesus Christ his Son cleanses us from all sin" (1 John 1:7). This language is not unique to Christianity. ${ }^{9}$ Sacrificial blood and sacred water are universal detergents to cleanse spiritual and social violations of the social and symbolic order. In the Hebrew Bible, trespasses against God's divine ordinances require expiation that take the form of rituals of purification, often involving the entire community, which is mandated to purify in response to violation of the sacred law. Unless the culprit is punished, the entire community is implicated in guilt by association, 
which pollutes the land, undermines social cohesion, and obstructs relations with G-d:

You shall not pollute the land in which you live; for the blood pollutes the land, and no expiation can be made for the land, for the blood that is shed in it, except by the blood of the one who shed it. You shall not defile the land in which you live, in which I dwell; for I the LORD dwell among the Israelites.

(Num 35:33-34)

On the Biblical paradigm, it is the entire community that is implicated and under obligation to respond, prosecute, and punish the culprit. Only some people in a community are guilty, but all are responsible. Unless and until a community vindicates the victims by imposing the rule of law, the pollution of moral violation spreads. ${ }^{10}$ While this may sound like an ancient tribal blood feud custom, we can see this dynamic clearly playing out in the current church crisis, which stems from the community's failure to mark wrong and punish wrongdoing. The cover-up becomes the pollution, in addition and quite distinct from the original crime of sexual predation. Retribution checks this contamination and restores moral health to the community. ${ }^{11}$ The scapegoat ritual provides the other setting by which a community rids itself of personal and communal guilt:

Then Aaron shall lay both his hands on the head of the live goat, and confess over it all the iniquities of the people of Israel, and all their transgressions, all their sins, putting them on the head of the goat, and sending it away into the wilderness by means of someone designated for the task. The goat shall bear on itself all their iniquities to a barren region; and the goat shall be set free in the wilderness.

(Lev 16:20-22)

This ritual visualizes sin and guilt as a burden that can be loaded and carried away. In Christianity, Christ takes on the role of sacrificial substitute who carries away the weight of iniquity and disposes it somewhere safely in a remote corner of the universe. This language must be challenged on moral and ecological grounds: The remainders of wrongdoing do not disappear magically, and they do not drain down mysterious pipes 
or vanish on the backs of waste management scapegoats. But these metaphors are suggestive and can be used to imagine new approaches to guilt contagion by association. A toxic pile radiates, pollutes, and contaminates. Guilt accrues as a result of a community's inability and unwillingness to censure evil and does not magically evaporate. It must be cleaned-up, bioremediated, and composted.

The metaphor of composting affirms the messy materiality of the past and enriches existing imagery of washing and waste removal. Composting the remainders of wrongdoing requires patience and engagement, strategy and supervision. The etymology of the word is derived from the Latin compositum (later compostum) which the OED defines as "(1) composition, combination, compound, (2) literary composition, compendium, as well as (3) a mixture of various ingredients for fertilizing or enriching land, a prepared manure or mould." ${ }^{2}$ It is the exact opposite of purity, which is defined as "the state or quality of being free from extraneous or foreign elements, or from outside influence; the state of being unadulterated or refined." Purity is white and clear, immaculate and untouched, while compost is rich, dark, smelly, and blended. When Pope John Paull II spoke of the "purification of memory" to guide the millennial celebrations in 2000, he invited the Church to come to terms with history, including the crusades, the inquisition, the slave trade, colonialism, and the Holocaust. ${ }^{13}$ He invoked the image of the Virgin Mary, whose purity consists of youth, innocence, and intactness. The old is never innocent, and that is true for individuals as much as for religious heritages and national histories. Age, inevitably, accumulates breakage and malfunction, failure and debris. By envisioning purity in the image of the Virgin, the untouched bride, "dressed in a simple robe of white linen, the finest linen, bright and pure" ${ }^{14}$ we scorn processes of maturation and ripening. By contrast, symbols such as fermented wine or leavened bread could be used to appreciate processes of fermentation and aging. Wine gets better with age. Sour dough enlivens tasteless and bland flour into flavorful bread. Purity that derives from composting validates the digestion of the old, broken, discarded, and the guilty into rich, new ground for being.

Even the most poisonous remainders can be digested into basic stable elements. Scientists have only recently begun to use composting for the most protracted cases, known as POC (persistent organic compounds) that resist natural biological degradation. Bioremediation proves promising 
and often successful. But even if it did not, what else, exactly, is supposed to happen to toxic garbage, including radioactive waste? Neither our material garbage nor our moral legacies dissolve into thin air. Composting sequesters detritus but does not pretend its magic elimination. The new always grows out of the old. Putrefaction and fermentation create the conditions in which the new takes root and grows.

The Catholic Church has a sacramental system of penance that lends itself to sustainable practices of critical engagement with past wrongdoing. Its performative sacramental process prescribes three distinct steps before absolution. This sacrament aims at spiritual reconciliation with God and is facilitated by an ordained priest, but its basic grammar is applicable to any process of repair of relationship and recovery of personal integrity. The three steps are: contritio cordis, heartfelt contrition, confessio oris, verbal confession, and satisfactio operis, acts of penitential restitution. They are self-explanatory. The most secular people expect culprits to show some remorse, to admit their wrongdoing, and to repair the damage as much as possible. These are the cues that people are looking for, for instance, when we watch prominent men who have been accused by the \#MeToo movement apologize and attempt to return to public life. In private and public, we decide, based on the performance of these steps, whether we are willing to grant forgiveness.

What makes the language of sacraments intriguing is precisely their performative, external character. Sacraments are "outward and visible signs of an inward and invisible grace." This makes them relevant to the real world, where actions count. It is the visible performance of penance that establishes credibility and integrity more so than the internal changes to the soul. Of course, Martin Luther was right to observe that the depth and quality of a person's contrition can never be measured or proven. Every apology is a performance, which may or may not be heartfelt. Luther concluded from this fact that contrition should not be made the condition of God's grace and justification. On his view, contrition is the gift of justification, which is received unconditionally and works to open the eyes and soften the heart. Penance and sanctification follow after this change of heart has occurred. God's unconditional justification works to convert the sinner and to generate internal feelings of remorse and contrition. 
Luther was right that contrition is a precious gift. The evidence that contrition is lacking and woefully incomplete is overwhelming. We certainly also observe that in the case of the Roman Catholic hierarchy. Just the other week, retired Pope Benedict XVI issued a statement blaming the "scandal of sexual abuse" on secular culture, declining faith in God, and resistance to the doctrinal authority of the church. His rambling letter left open the possibility that the scandal was caused by the audacity and insolence of the victims rather than the moral bankruptcy of the leadership. Pope Benedict XVI, who has controlled the highest levers of power in the Church for decades, does not feel any remorse. In his view, the injured party is the Church (and he himself) rather than the victims of clergy sexual abuse, who are barely mentioned. He does not apologize. ${ }^{15}$

How does one purify recalcitrance? Conversions do not happen instantaneously. They require time and active engagement, which makes the metaphor of composting apt and compelling. The Roman Catholic sacrament mandates a threefold engagement with wrongdoing: Contritio cordis cultivates intellectual recognition and moral knowledge of what has happened; confessio oris exacts transparency and seeks language that can convey the truth of events that are unimaginable and indescribable; satisfactio operis implements reparative action to recompense the victims and to work toward institutional change of the conditions that enabled the wrongdoing. This process is not chronological or sequential, there is no beginning, middle, and end. It is an interlocking spiral that is cumulative and transformative.

\section{Contritio Cordis: rituals of repudiation}

Contrition must be cultivated in rituals of repudiation, in which and through which communities mark wrongdoing. Rituals of repudiation are speech acts that take the form of, for instance, apologies, court room trials, and removal from power and authority. They are symbolic and exemplary and signal a community's normative negotiations over the boundaries of right and wrong. Without such rituals of condemnation, contrition does not emerge. As Paul Ricoeur pointed out in The Symbolism of Evil, evil "is not a taint that exists absolutely without reference to a field of human presence, to words that express defilement. A man is defiled in the sight of certain men, in the language of certain men. Only 
he is defiled who is regarded as defiled; a law is required to say it; the interdict is itself a defining utterance ... This 'education' of the feeling of impurity by the language which defines and legislates is of capital importance." ${ }^{16}$ As long as a community fails to mark the boundaries of good and evil, contrition does not emerge. As long as perpetrators, such as Cardinal McCarrick of Washington, DC, whose coercive escapades with seminarians had long been known, ascended through the ranks of power, there was no contrition. Apologies, criminal prosecution, and loss of power and authority create the preconditions for experiences of contrition. ${ }^{17}$

Apologies have become routinized. ${ }^{18}$ Words are cheap. But they still do not come easy. Apologies are contested, demanded, delivered, debated, rejected, or accepted. When a Pope (or head of state, or CEO) issues a formal apology on behalf of an institution, they signal a community's disavowal of practices, policies, and persons that were previously tolerated. Public apologies accept personal and institutional responsibility and denounce particular behaviors. Apologies remain controversial, and we can all think of instances, where apologies were refused or delivered halfheartedly. Successful aologies are not singular events, but are repeated. Germany, for instance, is routinely delivering apologies, when invited to commemorations, while Japan seems to assume, falsely, that one apology should suffice. ${ }^{19}$ To work as ritual events, apologies must be repeated and become better, more precise, and factually more accurate over time. The precision, veracity, and integrity of apologies provide a fairly precise measure of the degree of change after wrongdoing.

Court proceedings are another ritual of repudiation. Of course, it is usually only a few exemplary offenders who are brought to justice and subjected to the drama of indictment and defense, deliberation, and sentencing. The majority of criminals, in all societies, get away. But some are caught, prosecuted, and declared guilty. Their punishment follows a finely grained system of codes that mark the severity of the offense in the currency of pain and harm. The worse the offense the harsher the penalty. In the contemporary world, most societies measure crime in prison time. But historically, there have been other methods involving physical harm or financial compensation for lost eyes, teeth, limbs, and life. Punishments have always been symbolic forms of marking and renouncing wrongdoing and criminality. Over the course of history, communities have 
experimented with exile and expulsion, physical punishments, monetary restitution, stigmatization and enslavement. Modern Western societies seem to have settled on incarceration. This may require rethinking and revision. But while we may need to reconsider the nature of punitive pain in light of the crisis of mass incarceration, we cannot forego punishments altogether without risking communal complicity. Bishops may not need to go to prison, but their impunity signals lack of respect for victims. Punishments express a community's normative values that determine whose lives matter, who deserves protection, and whose voice shall be heard.

Rape, incest, and the sexual abuse of children have always been prohibited. But, despite universal criminalization, victims find it exceedingly hard to speak, to find support, to seek justice, and to move communities to sanction their tormenters. Even in war zones, victims of political and military mass rape know to remain silent. They cannot trust their own families to take their side over the side of their torturers. No victim of a Catholic priest could ever assume that their family, their teachers, their counselors, or the police would believe them..$^{20}$ The sexual exploitation of women and children is not a minor failure or marginal flaw but intrinsic to patriarchal organizations that prescribe silence and submission as the divinely ordained vocation of women and children. Vulnerability is compounded by invisibility and powerlessness. The "scandal of sexual abuse," which has gathered steam over the last twenty years, is the result of the cultural empowerment of women and children. For the most part, the Church hierarchy has resisted these changes and conspired to silence its most vulnerable and weak members.

Rituals of repudiation, in the form of apologies, court trials, and resignations, shift the discursive field. They also purge institutions in instrumental ways. The entire structure of an all-male, celibate hierarchy (Greek: hieros-archy $=$ sacred rule of priests) is at stake. Contrition involves more than recognition of individual failure and exemplary resignations to reconsider the power arrangements that have shaped distorted interactions between clergy and laity, men and women. Nobody knows, at this point in time, what new orders will emerge from this composting approach to the sexual abuse crisis. But this metaphor communicates a strong sense of hope that something will sprout from the toxic trauma of guilt. The recognition of fault will lead to new insights and perspectives. The community will learn to see with new eyes and hear with different ears. 


\section{Confessio Oris: rituals of transparency}

The shock of the brazen lies of the Roman Catholic hierarchy that calmly denied knowledge of sexual abuse for decades all the while frantically protecting its perpetrators from exposure, dismissal, and prosecution is only slowly sinking in. It has taken the tenacity of victims and their organizations, the detective work of investigative journalists, and the prosecutorial methods of state's attorneys' offices to break through the walls of denial. Now that these walls have been breached, academic research can begin, psychologists can survey and collect data, prepare statistical analysis and psychological theories. What are the causes and conditions of abuse, the scope and solutions? We have no idea. How long has this been going on? We do not know. The archives remain closed. Historians have not (yet) been given access to the files. As an institution, the Church resists requests for information as strenuously as any recalcitrant teenager. Why is a religion that professes faith in Christian reconciliation on the basis of contrition, confession, and satisfaction so utterly opposed to any and all of it?

It is, of course, exceedingly hard to put our most shameful and traumatic secrets into words. While not all religions practice confession, all religions value truth and truthfulness as signs of integrity and purity. In the Jewish and Christian traditions, confession is mandatory for teshuvah and repentance. While there is no mediating priest in the Jewish tradition, Maimonides interpreted the commandment in Leviticus 5:5 that "he shall confess the sin he has committed upon" the sacrificial sin offering at the altar, to make confession mandatory. Otherwise, he argued, "unspoken matters that remain in the heart are not significant matters" (Kiddushin 49b). The verbal articulation turns secret acts into real and actionable events. Confessions can be public or private, before God or a priest, communal or individual. The mandate for language and the quest for the truth is rooted in the insight that wrongdoing creates blind spots. Guilt shades the truth and thick layers of deception prevent its exposure.

The truth about sexuality is notoriously elusive. Human civilizations seem to swing between puritanism and promiscuity, double standards and moral panics. And yet, we will need truthful stories to create narratives that can write new laws, create new support structures, and invent new procedures that help people live embodied and sexual lives. How do 
we speak about sexuality and its violation? Which words will children use, how will women reclaim sexual agency, and perpetrators wrestle with their desires? What constitutes rape culture? How do we define the problem: male sexuality, homosexuality, pedophilia? Violence, assault, submission? Celibacy and abstinence? Consent, seduction, coercion? Speaking truthfully about sexuality has never been an easy task. Despite confession fatigue, we cannot leave it to the professional experts, the confessors and therapists, researchers and historians to define appropriate sexual conduct. We need the entire community, with its artists and musicians, poets and prostitutes to engage in truthful dialogue. That the truth will make us free, is a statement of faith that is more easily professed than practiced in embodied and institutionalized ways.

\section{Satisfactio Operis: rituals of penitential restitution}

Punishment, penance, and penitence have become problematic. In the mainline churches, including Roman Catholicism, the God of forgiveness, love, and mercy is emphasized. The God of wrath and revenge, who used to consign sinners to eternal hellfire or to temporary purgatory torture has fallen out of fashion. Liberal Christianity has become tolerant and conciliatory, and nothing seems unforgiveable to this God. Christians see themselves as peaceful and are exhorted to forgive their trespassers seven times seventy times (Mt 18:22). This abandons victims of atrocity who are denied retribution and vindication. The desire to see perpetrator suffer the consequences becomes immoral. The Latin word poena means pain, pun-


ing blood money, fine, penalty, and punishment. Of course, the line between punishment and abuse has always been exceedingly thin, and the historical experience of religious practices of flagellation and hair shirts, starvation and indulgences are not reassuring. Neither is the current state of the sprawling prison industrial complex. Penitential suffering could be a pointless exercise in cruelty.

Traditionally, the Church imposed penitential works of satisfactio operis alongside and in addition to retributive justice delivered by the "sword" of the state. Penances involved prayer and austerities, such as fasting, charity, abstinence, self-mortification, and self-denial and aimed at atonement and reconciliation. Restorative justice theorist Robin Antony Duff is intrigued by penitential practices because they seek to reform and reintegrate 
perpetrators into the community. ${ }^{21}$ Penances are pre-emptive and seek to avoid permanent exclusion by excommunication, exile, and execution. But penances are painful and deprive a person of status, honor, freedom, and money. Hard treatment, writes Duff is a structured exercise that aims to focus a "sinner's attention on his sin and its implication." ${ }^{22}$ Suffering, argues orthodox Jewish philosopher Dov Soloveitchik, is the "currency in which the sinner pays the Almighty to regain ownership over himself after he repents." ${ }^{23}$ Suffering redeems, changes, transforms. In modern secular socities, this link is no longer self-evident.

But there are other contexts, in which modern secularists accept physical suffering as productive and meaningful. Consider the difference between the physical pain of torture and the physical pain of extreme sports. One form is undertaken voluntarily, the other is inflicted against one's will, for different reasons and with different outcomes. While the physical pain itself may be similar, its meaning is different: Torture is debilitating and disempowering, while climbing Mount Everest is empowering and exhilarating. Penitential suffering should be compared more to hiking in the Himalayan mountains than to torture. Its torment is ennobling and ultimately rewarding. The difference is decisive and elusive, as any educator who penalizes bad behaviors, knows. One easily slips into the other.

What kinds of suffering could members of the Roman Catholic hierarchy undertake to channel retributive rage into reparative action that renews dignity and respect? A fast day for the entire Roman Catholic clergy? A public relinquishment of Church treasure to support the wellbeing of victims? A month of sackcloth for bishops? A vow of silence on matters of controlling the sexual lives of others? A day of remembrance to respect victims and survivors? The Pope crossing the Alps barefoot, as King Heinrich IV did from Germany to Canossa in 1076 to ask for forgiveness? There is actually little public appetite for such symbolic acts of degradation. But we should not discount their potential to preempt anger and to firm up resolve to engage in meaningful action. There is rich repertoire of penitential affliction that transforms silent, speechless shame into active obligation to reach out and serve. Rites of affliction cultivate contrition, elicit respect, and (re)generate trust. Rituals of penitential restitution include financial settlements, charity, and support for survivor organizations; administrative reform, the removal of implicated 
religious elites, education about sexuality, empowerment of women and children, dialogue, as well as commemorative events to honoro victims.

The call to "clean house" and purify the church easily means "whitewashing" or, worse, "sweeping the dirt under the rug." Sending predator priests into retirement (finally) and demoting their complicit supervisors, while huge, will not suffice. Guilt and the guilty do not magically disappear. Guilt must be decontaminated, remediated, composted in cycles of sustainable intervention and transformative strategies. It becomes the ferment that turns the refuse into new ground. Composting provides a productive and hopeful metaphor for purification, because it requires more than washing away the guilt. Instead, it approaches guilt as ferment and leaven that transforms the raw material of failure into life-giving wine and bread. Unless the patriarchal and feudal power arrangements that created the conditions for sexual abuse are decontaminated, fermented, and transformed, these wounds will fester.

\section{Notes}

1. Leys, Ruth, From Guilt to Shame: Auschwitz and After (Princeton: Princeton University Press, 2007).

2. Leys, Ruth, Trauma: A Genealogy (Chicago: Chicago University Press, 2000). https://www. nimh.nih.gov/health/topics/post-traumatic-stress-disorder-ptsd/index.shtml [January 9, 2019].

3. Moss, Thorsten, and Engert, Stefan, eds. Vom Umgang mit Schuld: Eine multidisziplinäre Annäherung (Frankfurt: Campus Verlag, 2016).

4. Borneman, John, Cruel Attachments: The Ritual Rehab of Child Molesters in Germany (Chicago: Chicago University Press, 2015).

5. Buber, Martin, Schuld und Schuldgefühle (Heidelberg: Verlag Lambert Schneider, 1958).

6. Buber, Schuld und Schuldgefühl, 114.

7. Ophir, Adi, The Order of Evils: Toward an Ontology of Moral, transl. by Rela Mazali and Havir Carel (New York: Zone Books, 2005).

8. Card, Claudia, The Atrocity Paradigm: A Theory of Evil (New York: Oxford University Press, 2002).

9. Douglas, Mary, Purity and Danger: An Analysis of Concept of Pollution and Taboo (New York: Routledge, 1966).

10. Kant, Immanuel, The Metaphysical Elements of Justice: Part I of the Metaphysics of Morals, (1797), transl. John Ladd, 2nd ed., (Indianapolis, 1999), 140.

11. Duncan, Martha Grace, Romantic Outlaws, Beloved Prisons: The Unconscious Meanings of Crime and Punishment (New York, New York University Press, 1996).

12. Oxford English Dictionary, online, third edition, (2007), s.v. Compost.

13. Pope John Paul II, Incarnationis mysterium, $\S 11$ Bull of Indiction of the Great Jubilee of the Year 2000, (November 1998), http://www.vatican.va/jubilee_2000/docs/documents/hf_jpii_doc_30111998_bolla-jubilee_en.html [accessed August 16, 2016]. International Theological Commission, Memory and Reconciliation (December 1999), §5.1. http://www.vatican.va/roman_ 
curia/congregations/cfaith/cti_documents/rc_con_cfaith_doc_20000307_memory-reconc-itc_en. html [accessed July 17, 2017].

14. Pope John PaUl II, Incarnationis mysterium, §11.

15. Pope Benedict XVI "The Church and the Scandal of Sexual Abuse," https://www.catho licnewsagency.com/news/full-text-of-benedict-xvi-the-church-and-the-scandal-of-sexual-abuse59639 [April 17, 2019].

16. Ricoeur, Paul, The Symbolism of Evil (Boston: Beacon Press, 1968), p. 36.

17. Seligman, Adam, et al., Ritual and Its Consequences. An Essay on the Limits of Sincerity (New York: Oxford University Press, 2008).

18. Gibney, Mark, et. al., eds. The Age of Apology: Facing Up to the Past (Philadelphia: University of Pennsylvania Press, 2008). Cf. http://www.humanrightscolumbia.org/ahda/political-apologies (May 10, 2019).

19. Berger, Thomas U., Guilt, War and World Politics after World War II (Cambridge: Cambridge University Press, 2012).

20. Cf. the seven-part TV Mini-Series directed by White, Ryan, The Keepers (2017) about the Baltimore Catholic highschool Bishop McKeough (https://www.imdb.com/title/tt6792200/) or The Arte documentary Gottes missbrauchte Dienerinnen, first shown March 5, 2019 and then forced offline April 23, 2019. Emnonts, Benjamin, "Arte nimmt Missbrauchs-Doku aus dem Programm,” Süddeutsche Zeitung (April 23, 2019). https://www.sueddeutsche.de/medien/artemissbrauch-kirche-doku-1.4418540 [accessed May 12, 2019].

21. Duff, Robin Anthony, "Penance, Punishment and the Limits of Community," Punishment and Society (July 2003) 5:295-312.

22. Duff, Robin Anthony, "Penance, Punishment and the Limits of Community" Punishment and Society (July 2003) 5:295-312.

23. Peli, Pinchas, ed. On Repentance: The Thought and Oral Discourses of Rabbi Joseph Dov Soloveitchik (New York: Paulist Press, 1984), p. 315. Blumenthal, David R., "Repentance and Forgiveness," CrossCurrents, 48.1 (Spring, 1998); Henry Abramson, Maimonides on Teshuvah: The Ways of Repentance, (Touro Scholar, 2017) https://touroscholar.touro.edu/cgi/viewcontent.cgi?ar ticle $=1000 \&$ context=lcas_books [January 12, 2019]. 